teachers is a shaping methodical means and the basis for the studying of their piano performance culture. The mature state of future Music teachers' performing culture means the achievement of the high level of the performance skills, music and aesthetic, professional and creative, special and spiritual development of their personality. The piano performance culture is considered as an integral personal quality, which is characterized by the mature state of general and special culture knowledge in the area of piano performance, as well as piano performance skills of the successful realization of artistic and pedagogical activity. It has been concluded that the structure of future Music teachers' piano performance culture consists of the following components: axiological, cognitive and linguistic, artistic and mental, activity and practical. The axiological component defines the conceptual essence of the piano performance activity and is characterized by its coherence with the system of special and personal values. Cognitive and linguistic component can be described by the maturity of professional and special music and interpretation knowledge acquired in the process of studying, understanding the conceptual and linguistic structure of piano compositions. Artistic and mental component is characterized by the individual and worldview potential of a student, and is manifested in professional personal orientation, the creation and understanding of the prospects of piano performance culture formation. Activity and practical component reflects the mechanisms of the acquisition of the piano performance culture.

Keywords: music culture, performance culture, piano performance culture, future Music teacher, axiological component, cognitive and linguistic component, artistic and mental component, activity and practical component.

Рецензент: д. мистецттвознавства, проф.. С. В. Шип

Подано до редакиії 09.06.2016

UDC: $378+78+81 ’ 22$

Sun Peng Fei, post-graduate student, Department of Music Art and Choreography, South Ukrainian National Pedagogical University named after K. D. Ushynsky,

4, Fontanska doroha Str., Odesa, Ukraine

\title{
ARTISTIC AND SEMIOTIC COMPETENCE OF FUTURE MUSIC TEACHERS AS AN ISSUE OF MUSIC PEDAGOGY
}

The paper is focused on the issue of forming artistic and semiotic competence of a music teacher in the context of music pedagogy. The main lines of research on this issue in contemporary music pedagogy have been determined. Specific qualities of music teacher's semiotic competence have been considered.

Keywords: sign, symbol, semiotic competence, musical language, music perception, pedagogical process.

Problem statement. Semiotic competence is one of the main bases for human functioning in the society, for one's social and cultural activities, which provides successful use of senses and symbolic information, knowledge, collective and individual experience. In musical and artistic activities, semiotic competence acquires special meaning and status as long as music as an art form uses a certain semiotic system. This very system embodies and reveals artistically imaginative meaning.

A music teacher of a comprehensive school is "immersed" in the truest sense of the word in the flow of various musical signs and meanings. Every lesson he/she faces the necessity of verbal explanation of the content of music that is heard or performed. One of the main tasks of a musician-pedagogue is to develop students' “... need and ability for "conscious perception" of music in order to "lead" them consistently from surface to deeper understanding of the intention of works" [9, p. 2-3]. For this reason, the use of the variety of semiotic system related to musical art and musical language will facilitate music teacher's own understanding of music and help him/her teach its conscious perception, which is the required qual- ity of a future musician-pedagogue and determinant for his/her successful professional activities.

Review of recent researches and publications. Despite the fact that music teacher's understanding of semiotic systems (not only in music) is important, the issue of semiotic competence in contemporary music pedagogy is still at the initial developmental stage.

In fact, some aspects of this issue were discussed in the first half of the $20^{\text {th }}$ century (pedagogical conceptions of L. Vygotskiy, P. Blonskiy, D. Kabalevskiy; basic principles of educating, artistic and educational work of B. Yavorskiy, B. Asafyev, N. Vetlugina, N. Grodzenskaya, O. Apraksina, K. Portugalov). In the recent decades, interest in semiotic competence and sign interpretative actions of a music teacher has significantly increased: the number of thesis researches, reports and scientific papers is constantly growing.

The aim of the paper is to determine the main trends of research on musical pedagogy in terms of music teacher's semiotic competence and investigate some of its specific qualities. 
Major content. It has become obvious these days that in any branch of human activity the understanding of semiotic systems and symbolism of objects and cultural phenomena is a necessary component of productivity and usefulness of this activity. For this very reason, semiotic competence is defined as "... key, transprofessional competence of a modern human, which includes a system of capabilities; cognitive and knowledge operations; value, motivational and semantic attitudes of a personality, which provide adaptation in the modern society, effective communication in a great number of semantic contexts, efficient work with information and knowledge in educational activities" [2, p. 75]. This definition of the phenomenon under study demonstrates its complex nature and complicated structure that covers a great number of mental and intellectual processes of human activities. Moreover, the above mentioned definition emphasizes versatility of the semiotic competence as long as it affects a variety of aspects of human life: cognitive and professional activities; value, motivational and communicative contexts of these activities and even personality's social adjustment.

In music teacher's work, his/her semiotic competence can be manifested in two ways: a) as a part of didactic activity; b) as a basis for the teacher's own musical consciousness. In the first case, the high-priority task is manifested, which is to influence pupils with the aim of introducing sign properties of musical and acoustic forms to them, preparing for comprehending perception and reflexive understanding of the content of music compositions. It also involves one of the foremost pedagogical aims - to develop pupils' need for conscious perception of music.

On the other hand, music teacher's qualification is determined by the quality of knowledge, abilities and skills, which make it possible for him/her to be familiar with the semiotic system of musical art (particularly with the elements and principles of musical language), to apply this knowledge in the teaching process as a means of explaining and understanding the music content.

For this very reason, music teacher's semiotic competence is often considered as a technological component of musician-pedagogue's professional competence. "Semiotic competence of a teacher in artistic and pedagogical activities makes a synthesis of symbolic generalizations and semantic ties between them, which are the basis for teacher's pedagogical technology as well as the ability for understanding semantic context of communication. Pedagogical technology involves wide use of signs-copies graphic modules that convey similarity with real-life objects; signs-descriptors associated with denoted objects as a consequence with its reasons; signs-symbols as abstract images of significant ethic, spiritual and metaphoric content", notes Ye. Kurolenko [4, p. 3].

In similar arguments, it is referred to using symbolic structures in music teacher's work as a pedagogical means or method aimed at the achieving of a certain goal - conscious perception of music. The study of semiotic competence as a professional quality of a musician-pedagogue from such a point of view is reasonable as long as in everyday work he/she faces "problems of translating" music content and meaning into verbal structures in order to tell pupils "what the heard music means and what it is about". It is also obvious that teacher's conscious attitude to the main "instrument" of communication with pupils - verbal speech - is reasonable. The teacher should choose verbal means and other signs that should be used in a certain case consciously and skillfully. In one case, it is comparison with an object or phenomenon, in the second one - it is emphasizing an attribute of music content, in the third one - applying more neutral images-concepts for explaining spiritual and philosophic content of a music piece, etc.

In any case, music teachers need conscious knowledge on signs used in musical art and the ones he/she uses when explaining pieces of music. For example, there is the need for classifying the signs used by teachers as the means of explaining the music content. It is also necessary to be aware of different levels of learning signs by students: subject (denotatum), grammatical (concept), connotative (situational context).

Consideration of the structural properties of a sign in the relation to the specificity of musical language and speech is a subject of a number of contemporary musicological researches; however, very few authors are interested in semiotic aspects of music pedagogy $[9 ; 10]$.

Denotatum in logics and semantics is a thing or a phenomenon denoted by a certain name (concept). In music and art, denotatum is “... a variety of properties and relations reflected in sensually specific, emotionally coloured images-notions" [9, p. 4].

Grammatical level is usually understood as "... a generalized abstract linguistic meaning peculiar to a number of words, word forms, syntactic constructions, which have their regular (standard) expression in a language" [5, p. 116].

Connotative level is traditionally defined as "... a component that complements objective and notional (denotative) as well as grammatical content of a linguistic unit and provides it with the expressive function on the basis of information related to empirical, cultural and historical, worldview knowledge of people speaking a certain language; emotional and axiological attitude to the denoted or stylistic levels characterizing communication conditions; the sphere of linguistic activities, social relations of communication participants, its form, etc." [5, p. 236].

In S. Shyp's opinion, connotative level is most of all connected with the personality of a musician-pedagogue as long as it is derived directly from symbolic form, but "thought up" to the basic meaning due to the fact that this symbolic thing is associated in person's consciousness with some other signs or texts, speech situations, human personality, historical events, ideas, etc. In other words, connotative meaning is more often developed due to the context $[9$, p. 7].

The concept of the context considered by S. Shyp in relation to connotative levels of signs used in verbal speech is directly related to the main characteristics of music teachers' semiotic competence. It includes teach- 
er's knowledge on the information and semiotic field of certain culture, his/her individual artistic experience, motivation for self-improvement by means of creative experience and activities, knowing the variety of artistic culture, capability for independent and creative selection of signs and symbols of culture in the pedagogical process. All these characteristic are essential in forming future music teacher's semiotic competence; each of them is related to personal motivation and axiological orientations of a musician-pedagogue.

In order to use the signs and symbols of artistic culture properly, it is necessary to have deep knowledge of this culture. Moreover, for a music teacher this knowledge should exceed the limits of musical art itself. Provided that the teacher is familiar with the world of literature, poetry, painting and theatre, he/she is able to use verbal language completely and properly when explaining the meaning of a music piece, i.e. in the process of its interpretation aimed at understanding (if we use hermeneutic terminology).

Thus, the concept of the context, in our opinion, is one of the main in the structure of semiotic competence of a musician-pedagogue as long as it denotes the information field that forms individually personal level of his/her expertise. And in this regard, it is reasonable to refer to the remark of S. Shyp about the fact that the problem of misunderstanding a music text if often determined by "... insufficient cultural competency, i.e. qualitatively poor verbal, artistic and life experience, which prevents from recognizing and understanding connotative meanings of linguistic signs" [9, p. 10].

The attitude to a piece of music as to a symbolic structure (text) and awareness of the need for its understanding in the process of training determined academic interest of music pedagogy in the ideas of music hermeneutics and its application in teaching practice $[3 ; 6 ; 9]$ Basing on the basic ideas and principles of classical hermeneutics, which were formed as methodological basis for the theory of understanding in the European humanities knowledge (F. Shleiermacher, V. Dilthey, M. Heidegger, G. Gaddamer), contemporary researchers offer their own explanations of interpretation art under conditions of teaching music.

For example, S. Malkin [6] associates the effectiveness of hermeneutic approach in music pedagogy with frequently arising difficulties of explaining artistic imagery and the content of contemporary composers' music pieces that are different from classical music. Assuming that the key concepts of hermeneutics are the concepts of meaning and language of a text, the author determines the central problem of musical and pedagogical interpretation as follows: proper correlation between personal experience and the levels of semiotic competence of a teacher and students in the teaching process. "Pedagogical interpretation is, probably, the most complicated and multisided form of musical interpretation. A music teacher faces quite a challenging task to not only understand and use music material, but to convey it to pupils in two as- pects - as an unchanged authentic work and as a specially prepared interpreted in a many-sided way training resource corresponding to the training and personal characteristics of students both in terms interpretation level and orientation of the interpretation", notes S. Malkin [6, p. 4]. Basic principle of solving this problem involves, in $S$. Malkin and other researchers' opinion, the development of the above mentioned "information field", which forms semantic and content-related context of teacher's orientation in semiotic systems of contemporary music.

The process of hermeneutic work on music (explaining) involves three stages: learning the subject of explanation (musical note text), pre-understanding (initial idea about a piece of music) and interpretation (explanation aimed at understanding the meaning). Consequently, a musicianpedagogue should have three necessary qualities corresponding to these three stages: the ability to "read" musical symbols, which is particularly important for explaining contemporary music as long as its notation differs greatly from the classical one; knowledge of musical (and artistic in general) culture, its signs, symbols, which determines preunderstanding of a music piece; command of the verbal language, which makes it possible to explain the content of music at verbal and notional level (i.e. to carry out the process of musical and pedagogical interpretation).

One more problem field of contemporary music pedagogy, which is directly connected with music teacher's semiotic competence, is covered in the researches considering pedagogical capacity of a symbol in terms of interpreting musical images $[1 ; 8]$. Despite the fact that symbolic means have become a regular practice of artistic didactics, their didactic potential has not been sufficiently theoretically developed. At the same time, some pedagogues write that "... vivacity, external expressiveness of symbols is easily perceived by the child's psyche, provides opportunities for experiencing generalized meaning that is implied, and makes them multifunctional means of pedagogical interaction..." [8, p. 2]. For example, A. Bondarev points out at the fact that the method of verbal interpretation is based on a symbolic image, which makes it possible to carry out "...multi-sided consideration of a music image" [1, p. 5]. In pedagogical interpretation, using symbolic images, in the author's opinion, facilitates students' creative understanding of musical imagery.

In the thesis by G. Manasova [8], for example, the effectiveness of using the symbols in the educational process is discussed, and a number of conditions providing its effectiveness are proposed. There are two the most influential: "the teacher has axiological perception of the world, which is the basis for his/her mental activity on creating mew symbols; the teacher has comprehensive understanding of approaches to symbols classification, chooses and uses various types of symbolic means that correspond to the approaches and are the most appropriate in a certain training situation" $[8, \mathrm{p} .5]$.

Such understanding corresponds to classical philosophic foundation of the development of pedagogical opportunities of a symbol as long as symbols are one of 
the forms of human consciousness. M. Mamardashvili considers symbols as specific manifestations of life of consciousness: "First of all, symbol for us is not just related to thoroughness of consciousness, but it is the thing that corresponds really and materially to something definite in the content of consciousness" [7, p. 159]. In our opinion, this point of view is of great importance as long as it contains a useful methodological attitude: the use of symbols always influences consciousness, extracting unaffected personal experience (life, artistic, etc.). In this case, the process of its understanding facilitated by symbols is an "instrument" that forms and "creates" consciousness of both the teacher and students.

Summarizing the above mentioned arguments, the author has drawn the following conclusions:

1. Semiotic competence of a future music teacher should be considered in contemporary music pedagogy as the most important component of teacher's qualification.

\section{ЛИТЕРАТУРА}

1. Бондарев А. А. Педагогическая интерпретация музыкального образа (теоретические и методические аспекты изучения музыки С. В. Рахманинова) : автореф. дисс. ... канд. пед. наук: специальность 13.00.02 - Теория и методика обучения и воспитания (музыка) / А. А. Бондарев. - М., 2002.

2. Гончаров С. А. Семиотическая компетентность в образовании и социуме / С. А. Гончаров, О. М. Гончарова, Н. Н. Королёва // Universum: Вестник Герценовского университета. - 2011/8. - С. 75-76.

3. Давыдова С. А. Предмет «Музыкальное содержание» в аспекте герменевтики (начальная школа) : автореф. дисс. ... канд. пед. наук : специальность 13.00.02 - Теория и методика обучения и воспитания (музыка) / С. А. Давыдова. - Санкт-Петербург, 2011. $-24 \mathrm{c}$

4. Куроленко Е. М. Семиотика художественнопедагогической деятельности [электронный ресурс] / Е. M. Куроленко. - Режим доступа: http://www.emissia.org/offline/2012/1738.htm.

5. Лингвистический энциклопедический словарь / Гл. ред. В. Н. Ярцева. - М. : Советская энциклопедия, 1990. -685 с.

\section{REFERENCES}

1. Bondarev, A. A. (2002). Pedagogicheskaya interpretatsiya muzykalnogo obraza (teoreticheskie i metodicheskie aspekty izucheniya muzyki S. V. Rachmaninova) [Pedagogical interpretation of a musical image (theoretical and methodological aspects of studying music)]. Extended abstract of candidate's thesis. Moscow [in Russian].

2. Goncharov, S. A., Goncharova, O. M., \& Koroleva, N. N. (2011). Semioticheskaya kompetentnost v obrazovanii i sociume [Semiotic competence in education and society]. Universum: Vestnik Gertsenovskogo universiteta - Universum: Bulletin of Gertsen University, 8, 75-76 [in Russian].

3. Davidova, S. A. (2011). Predmet «Muzikalnoe soderzhanie» V aspekte germenevtiki (nachalnaya schkola) [The
2. It is reasonable to develop musical and pedagogical researches on the issue of forming semiotic competence in three lines: in keeping with the hermeneutic approach, development of pedagogical capacity of symbols in training process as well as correlation of the theory of semiotic systems with the specificity of musical language and, correspondingly, semiotic bases of music pedagogy.

3. The most essential specific qualities of music teacher's semiotic competence are the following: a) the ability to "read" musical signs of a music note text; b) personal artistic (acoustic, visual, performing) experience, which makes it possible to form initial idea of a piece of music; c) knowledge in the sphere of signs and symbols of artistic culture that gives an opportunity to preunderstand the meaning conveyed by musical signs; d) high level of verbal speech, which can provide proper explanation of the meaning and the content of a piece of music using words and notions.

6. Малкин С. Ю. Идеи герменевтики в музыкально-педагогическом образовании / С. Ю. Малкин // Современные проблемы науки и образования. - 2015. - № 5 [интернет-ресурс]. - Режим доступа: http://science-education.ru/ru/article/view?id=21912.

7. Мамардашвили М. К. Символ и сознание / М. К. Мамардашвили, А. М. Пятигорский. - М. : Языки русской культуры, 1999. - 216 с.

8. Манасова Г. Н. Педагогический потенциал символов в истории и современной отечественной практике образовательного процесса : автореф. дисс. ... канд. пед. наук : специальность 13. 00. 01 «Общая педагогика, история педагогики и образования» / Г. Н. Манасова. - Владимир, 2007. - 21 с.

9. Шип С. В. О семиотических основаниях музыкально-педагогической герменевтики / С. В. Шип // Наука i освіта. Науково-практичний журнал Південного наукового центру АПН України. - Одеса, № 4-5, 2004. - С. 210-214.

10. Шип С. Музыкальная речь и язык музыки / С. Шип. - Одесса : Изд-во Одесской гос. консерватории им. А. В. Неждановой, 2001. - 298 с.

subject "Music content" in hermeneutical aspect (primary school)]. Extended abstract of candidate's thesis. St. Petersburg [in Russian].

4. Kurolenko, Ye. M. (n.d.). Semiotika khudozhestvenno-pedagogicheskoy deyatelnosti [Semiotics of artistic and pedagogical activities]. Retrieved from: http://www.emissia.org/offline/2012/1738.htm [in Russian].

5. Yartsev, V. N. (Eds.). (1990). Lingvisticheskiy entsiklopedicheskiy slovar [Linguistic encyclopedic dictionary]. Moscow: Sovetskaya entsiklopediya [in Russian].

6. Malkin, S. Yu. (2015). Idei germenevtiki v muzykalno-pedagogicheskom obrazovanii [Hermeneutic ideas in musical and pedagogical education]. Sovremennie problemy 
nauki i obrazovaniya - Contemporary problems of science and education, 5. Retrieved from: http://scienceeducation.ru/ru/article/view?id=21912 [in Russian].

7. Mamardashvili, M. K., \& Pyatigorskiy, A. M. (1999). Simvol $i$ soznanie [Symbol and consciousness]. Moscow: Yazyki russkoy kultury [in Russian].

8. Manasova, G. N. (2007). Pedagogicheskiy potentsial simvolov $\mathrm{v}$ istorii i sovremennoy otechestvennoy praktike obrazovatelnogo protsessa [Pedagogical capacity of symbols in historically and in modern education]. Extended abstract of candidate's thesis. Vladimir [in Russian].
9. Ship, S. V. (2004). O semioticheskikh osnovaniyakh muzykalno-pedagogicheskoy germenevtiki [About semiotic fundamentals of musical and pedagogical hermeneutics]. Nauka i osvita. Naukovo-praktychnyi zhurnal Pivdennoho naukovoho tsentru APN Ukrainy - Science and education. Academic journal of the Southern Centre for Research of NAES of Ukraine, 4-5, 210-214. Odesa [in Russian].

10. Ship, S. (2001). Muzykalnaya rech i yazyk muzyki [Musical speech and language of music]. Odesa: Izdatelstvo Odesskoy gosudarstvennoy konservatorii im. A. V. Nezhdanovoy [in Russian].

\section{Сунь Пенфей, \\ аспірант кафедри музичного мистеитва і хореографіï, Південноукраїнський наџіональний педагогічний університет імені К. Д. Уиинського, вул. Фонтанська дорога, 4, м. Одеса, Украӥна}

\section{ХУДОЖНЬО-СЕМІОТИЧНА КОМПЕТЕНТНІСТЬ МАЙБУТНІХ УЧИТЕЛІВ МУЗИКИ ЯК ПРОБЛЕМА МУЗИЧНОЇ ПЕДАГОГІКИ}

Метою статті є визначення поняття семіотичної компетентності майбутнього вчителя музики, а також основних напрямків дослідження цієї властивості особистості вчителя. Стверджується, що вчитель музики повинен володіти широким полем знакових засобів музичного мистецтва, тобто - мовою музики. Глибоке знання музичної мови дозволяе музикантові-педагогу повноцінно розуміти найскладнішу музику. Семіотичні знання потрібні вчителю також для того, щоб допомогти учням сприймати та розуміти музику. Таким чином, семіотична компетентність - необхідна якість майбутнього вчителя музики. Від цієї якості залежить успішність його професійної діяльності. Семіотична компетентність являє собою цілісну якість. Вона включає в себе ряд навичок, знань та вмінь, які дозволяють орієнтуватися в знаковій системі музичної мови. Ці навички, знання та вміння потрібні вчителю як «інструмент» роз'яснення учням образного змісту складних творів музичного мистецтва. Автор також робить висновок про те, що музично-педагогічні дослідження проблеми формування семіотичної компетентності доцільно розвивати в трьох напрямках: в руслі герменевтичного підходу, розробки педагогічного потенціалу символів у процесі навчання, а також співвіднесення теорії знакових систем зі специфікою музичної мови і, відповідно, семіотичних підстав музичної педагогіки. Серед специфічних якостей семіотичної компетентності вчителя музики найбільш істотними є: а) вміння «читати» знаки нотного тексту; б) наявність особистого художнього (слухового, зорового, виконавського) досвіду, що дозволяє складати попереднє уявлення про музичний твір; в) орієнтація в сфері знаків і символів художньої культури, що дає можливість «передрозуміти» сенс, відображений в музичних знаках; г) високий рівень вербальної мови, який може забезпечити адекватне словесно-понятійне роз'яснення смислу та змісту музичного твору.

Ключові слова: знак, символ, семіотична компетентність, музична мова, сприйняття музики, педагогічний процес.

Сунь Пенфей,

аспирант кафедры музыкального искусства и хореографии, Южноукранский национальный педагогический университет имени К. Д. Ушинского, ул. Фонтанская дорога, 4, г. Одесса, Украина

\section{ХУДОЖЕСТВЕННО-СЕМИОТИЧЕСКАЯ КОМПЕТЕНТНОСТЬ БУДУЩИХ УЧИТЕЛЕЙ МУЗЫКИ КАК ПРОБЛЕМА МУЗЫКАЛЬНОЙ ПЕДАГОГИКИ}

Цель данной статьи - определить понятие семиотической компетентности будущего учителя музыки, наметить основные направления исследования этого свойства личности учителя. Утверждается, что учитель музыки должен владеть обширным полем знаковых средств музыкального искусства, то есть - языком музыки. Глубокое знание музыкального языка позволяет музыканту-педагогу полноценно понимать самую сложную музыку. Семиотические знания нужны учителю также для того, чтобы помочь ученикам воспринимать и понимать музыку. Таким образом, семиотическая компетентность - необходимое качество будущего учителя музыки. От этого качества зависит успешность его профессиональной деятельности. Семиотическая компетентность представляет собой целостное качество. Оно включает в себя ряд навыков, знаний и умений, которые позволяют ориентироваться в знаковой системе музыкального языка. Эти навыки, знания и умения нужны учителю как «инструмент» разъяснения ученикам образного содержания сложных произведений музыкального искусства. Автор также делает вывод о том, что музыкально-педагогические исследования проблемы формирования семиотической компетентности целесообразно развивать в трёх направлениях: в русле герменевтического подхо- 
да, разработки педагогического потенциала символов в процессе обучения, а также соотнесения теории знаковых систем со спецификой музыкального языка и, соответственно, семиотических основаниях музыкальной педагогики. Среди специфических качеств семиотической компетентности учителя музыки наиболее существенные суть: а) умение «читать» знаки нотного текста; б) наличие личного художественного (слухового, зрительного, исполнительского) опыта, позволяющего составлять предварительное представление о музыкальном произведении; в) ориентация в сфере знаков и символов художественной культуры, дающая возможность «предпонимать» смысл, запечатленный в музыкальных знаках; г) высокий уровень вербальной речи, который может обеспечить адекватное словесно-понятийное разъяснение смысла и содержания музыкального произведения.

Ключевые слова: знак, символ, семиотическая компетентность, музыкальный язык, восприятие музыки, педагогический процесс.

Подано до редакиії 09.06.2016

Рецензент: д. мистецттвознавства, проф.. С. В. Шип

УДК: 611.718: [61-057.875-055.2]-071.3

Константин Анатольевич Бугаевский, кандидат медицинских наук, дочент кафедры физической реабилитации и здоровья, Классический Приватный Университет, ул. Жуковского 70-б, г. Запорожье, Украина

\section{АНАТОМИЧЕСКИЕ И МОРФОЛОГИЧЕСКИЕ ОСОБЕННОСТИ ТАЗА В СОМАТОТИПАХ ПО КЛАССИФИКАЦИИ ДЖ. ТАННЕРА У СТУДЕНТОК СПЕЦИАЛЬНОЙ МЕДИЦИНСКОЙ ГРУППЫ}

В статье представлены результаты исследования, посвящённые выявлению анатомических и морфологических особенностей костного таза девушек-студенток I курса специальной медицинской группь медицинского университета. Целью исследования было определить особенности размеров, строения и имеющихся изменений таза, а также ряда антропомотрических и морфологических индексных значений в половых соматотипах у студенток, согласно классификачии Дж. Таннера. Данные, полученные в результате антропометрии, пельвиометрии и определения значений специальных индексов, указывают на имеющиеся анатомические, морфологические и функциональные изменения со стороны костного таза, в основном в виде увеличения доли узких тазов, с I-III степенями сужения. Полученные данные свидетельствуют о патологических прочессах со сторонь репродуктивной системы у студенток данной специиальной медицинской группьл.

Ключевые слова: соматотипы, таз, антропометрия, пельвиометрия, морфологические индексы, студентки

Постановка проблемы. Здоровье - это проблема не только медицинская, но и социальнопедагогическая. Мониторинг изучения состояния уровня здоровья девушек-студенток в системе управления качеством образования является одной из актуальных проблем в современной педагогической науке $[4,11]$. Эта проблема является важной составляющей учебно-воспитательного процесса и напрямую связана с количеством студентов в ВУЗах, их способностью к учёбе, выполнению профессиональных и социальных функций, к процессу стабильности в деятельности учебных заведений разного уровня и профиля $[4,11]$. Большинство современных девушек, в особенности студенток, в юношеском и первом репродуктивном возрасте испытывают на себе влияние значительных физических и психоэмоциональных нагрузок, связанных с дезадаптацией в период первых лет обучения в современных ВУЗах $[2,4,11]$. Поэтому актуальным является исследование здоровья студен- ток как важного звена педагогического процесса и особой социальной группы с высоким риском функциональных нарушений организма $[2,4,11,19]$.

Особый интерес представляет комплексное изучение анатомо-антропологических и морфологических показателей, в частности размеров костного таза у девушек юношеского и первого репродуктивного возраста. Развитию костного таза у девушек этих возрастных групп придается большое значение, так как, с одной стороны, его строение влияет на исход родов, с другой - темпы его развития являются одним из показателей динамики их физического и полового развития $[5,6,17]$. Поэтому актуальными, в том числе и с точки зрения педагогической науки, являются исследования, посвящённые процессу формирования костного таза в этом возрасте, с учётом конституции и распределения по половым соматотипам по классификации Дж. Таннера. 